\title{
硝子の着色に關なる研究 (續)
}

\section{不破橘 三}

\section{7. 酸化ニツケルを加へた硝子の色}

ンツヶルによる硝子の着色に就ては本誌大正一一年九月に其の大體を發表した。

（a）硝子の成分と着色狀況並びに補助劑による着色の影響。

\begin{tabular}{|c|c|c|c|c|c|}
\hline 确子番號 & $\begin{array}{l}\text { 酸化=ツケ } \\
\text { ル 量 \% }\end{array}$ & $\begin{array}{l}\text { 酸化劑 } \\
\text { 量\% }\end{array}$ & $\begin{array}{l}\text { 還元劑 } \\
\text { の量\% }\end{array}$ & $\begin{array}{l}\text { 亞䂣酸 } \\
\text { 》)量\% }\end{array}$ & 矿子 の色 \\
\hline 10201 & 0.1 & - & - & - & 帶褐色 \\
\hline 10202 & 0.25 & - & - & - & 帶褐色に少しく赫味を持つ \\
\hline 10203 & 0.75 & 一 & - & - & 濃い帶蝎紫色 \\
\hline 10204 & 1.0 & - & - & - & 澧さな堽す \\
\hline 10205 & 1.5 & - & - & - & 一一尿濃くなり赤味し增す \\
\hline 10206 & 0.5 & 1.0 & - & - & 帶紫褐色 10203 より少し淡い \\
\hline 10207 & 0.5 & - & 1.0 & - & 赫味あろ帶褐色 \\
\hline 10208 & 0.5 & - & - & 1.0 & 赤味おろ紫禓色 \\
\hline 10221 & 0.1 & - & - & 一 & 鮮明な紫色 \\
\hline 10222 & 0.5 & - & - & 一 & 濃き美しき紫色 \\
\hline 10223 & 1.0 & - & 一 & - & 一磻濃され賭す \\
\hline $1022 \pm$ & 0.5 & 1.0 & - & - & 10222 と同じ \\
\hline 10225 & 0.5 & - & 1.0 & - & 10222 より少しく淡い \\
\hline 10226 & 0.5 & - & - & 1.0 & 濃き紫色 \\
\hline$\sum^{N}(10241$ & 0.1 & - & - & - & 褐色赤味があろ \\
\hline 10242 & 0.5 & - & - & - & 濃い赤味のあろ紫色 \\
\hline 10243 & 1.0 & - & - & - & 濃紫色 \\
\hline 10241 & 0.5 & 1.0 & - & - & 30212 より少しく濃し \\
\hline$\sum_{\infty}^{\infty} \mid 10215$ & 0.5 & - & 1.0 & - & 濃き赤味胅の褐色 \\
\hline $102 \pm 6$ & 0.5 & - & - & 1.0 & 10242 と同じ \\
\hline$\approx(10261$ & 0.1 & - & 一 & - & 淡き藤紫色 \\
\hline \begin{tabular}{l|l}
$\ddot{z}$ & 10262
\end{tabular} & 0.5 & - & - & - & 鮮明な紫色 \\
\hline 10263 & 1.0 & - & - & - & 一尿濃し \\
\hline $1026 t$ & 0.5 & 1.0 & - & - & 10262 より濃し \\
\hline \begin{tabular}{l|l}
$\ddot{4}$ & 10265
\end{tabular} & 0.5 & - & 1.0 & - & 赤褐色を帶びたっ色 \\
\hline - & 0.5 & - & - & 1.0 & 1022 と同じ \\
\hline 10281 & 0.1 & - & - & - & 淡い褐色 \\
\hline $102 ; 2$ & 0.5 & - & - & - & 紫色 \\
\hline 10233 & 1.0 & $\rightarrow$ & - & - & 濃い紫色 \\
\hline 10284 & 0.5 & 1.0 & - & - & 紫色 \\
\hline 10285 & 0.5 & - & 1.0 & - & 赤味め万褐紫色 \\
\hline 10286 & 0.5 & - & - & 1.0 & 紫色少しく办味がある \\
\hline
\end{tabular}




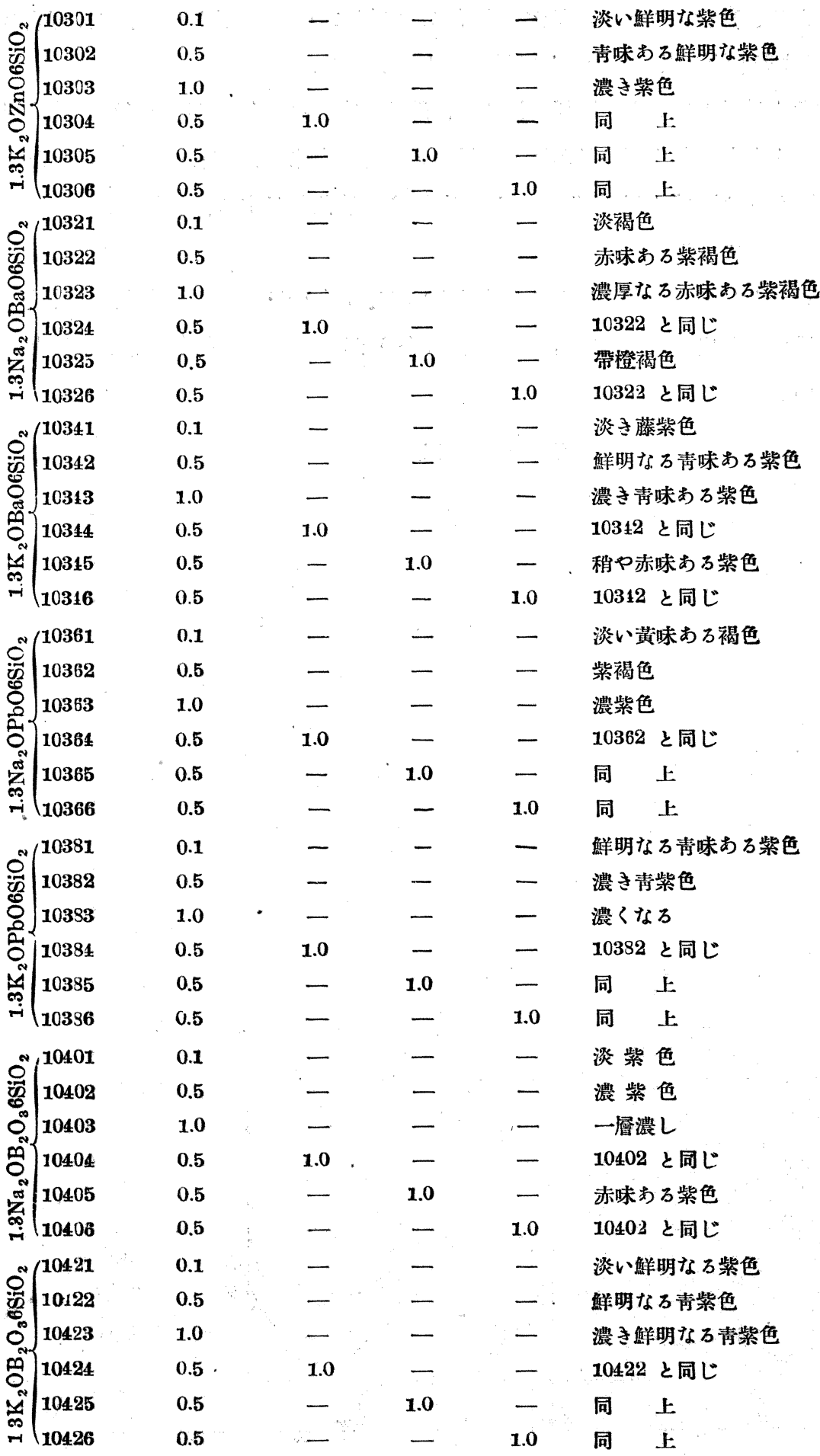

酸化ニツヶルを各種の成分の硝子に加へて其等の硝子の色を見ると酸化ニツケルの量の篔加す 
るに從ひ着色涱くなる、酸化=ツヶルの量が $0.1 \%$ に於て既に $5 \mathrm{~mm}$ の厚さの硝子には可成の着 色がある。1.0\%では着色餘り漫くて透過して見難いるのがある。

酸化=ツケルの色と硝子の成分との關係を見ると。硝子の成分の $\mathrm{R}_{2}^{\prime} \mathrm{O}$ が $\mathrm{Na}_{2} \mathrm{O}$ の時は褐色 を帶びた暗色のものとなり、着色劑の量が增すに從がい褐色は赤味を帶び來り赤暗紫色となる。 然るに $\mathrm{R}_{2} \mathrm{O}$ が $\mathrm{K}_{2} \mathrm{O}$ の時は鮮明な着色をなし靑味 勝ちの紫色を呈する、着色劑が䨛すに從ひ 青味ある紫色が濃くなつて來る。

成分中の $\mathrm{R}^{\prime \prime} \mathrm{O}$ の變化に就ては際立ちたる相違はないが. $\mathrm{R}^{\prime \prime} \mathrm{O}$ が $\mathrm{PbO}$ の時は同じ分量の着 色劑に對して幾分濃い色を出す、叉 $\mathrm{B}_{2} \mathrm{O}_{3}$ の硝子は $\mathrm{R}_{2}{ }_{2} \mathrm{O}$ が $\mathrm{Na}_{2} \mathrm{O}$ でも褐色を帶びるてとが他 のもの程著しくなん。

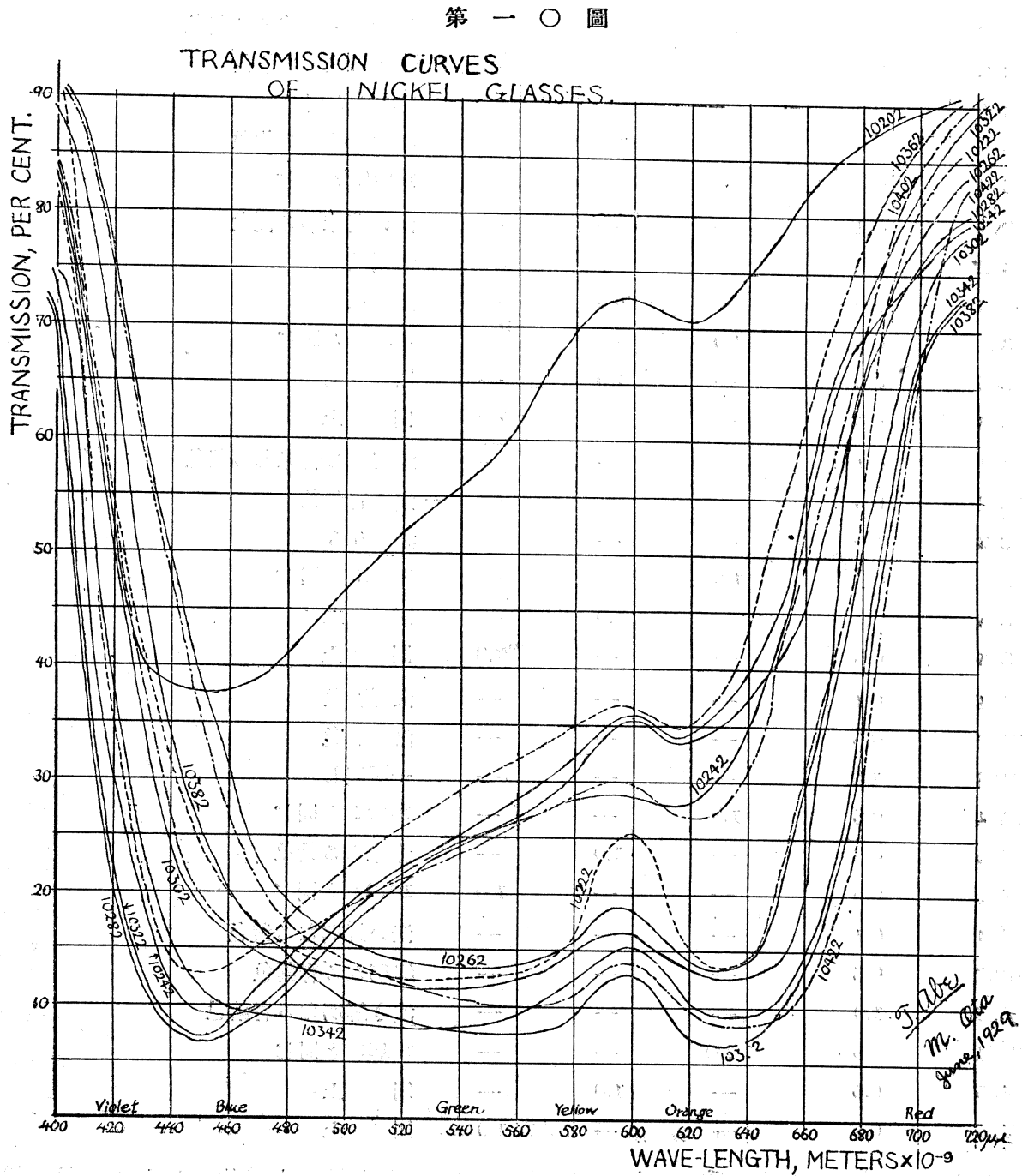


酸化ニツケルと同時に酸化劑、還元劑又は亞砒酸を加へたときの色の影響を見るに、酸化䰜を 加へたもの及び亞砒酸を加へたものとは殆んど影響なく、還元劑を加へたものは幾分着色が淡く なる又其の硝子の成分が $\mathrm{Na}_{2} \mathrm{O}$ なるときは黃褐色を帶び、 $\mathrm{K}_{2} \mathrm{O}$ なるときは殆んど影響がない。

(b) 酸化=ツヶルを加へた硝子の透過曲線と透過スペクトル。

(i) 透過曲線

酸化ニツケルを加へた硝子の透過曲線は酸化コバルトを加へを硝子の透過曲線を測定した場合 と全く同一で、Hilgar の Sector Photometer を使用した。

曲線に記した數字は硝子番號を表はし、試驗體の厚さは次の如きものである。

$\begin{array}{cccccc}\text { 确子番號 } & \text { 厚さ }(\mathrm{mm}) & \text { 确子番號 } & \text { 厚さ }(\mathrm{mm}) & \text { 确子番號 } & \text { 厚さ }(\mathrm{mm}) \\ 10202 & 1.6 & 10282 & 1.5 & 10362 & 1.1 \\ 10222 & 1.5 & 10302 & 1.3 & 10382 & 1.2 \\ 10242 & 1.4 & 10322 & 1.3 & 10402 & 1.2 \\ 10262 & 1.3 & 10342 & 1.3 & 10422 & 1.2\end{array}$

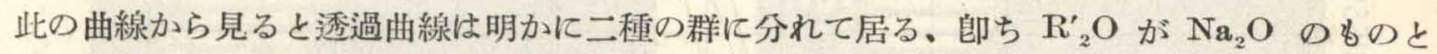
$\mathrm{K}_{2} \mathrm{O}$ のものとが明膫に區別することが出來る。・ $\mathrm{Na}_{2} \mathrm{O}$ の硝子の透過曲線は $480 \mu \mu$ より上景し $580 \mu \mu$ から $620 \mu \mu$ の間に小山を生じ再び上昇して居る。 $\mathrm{K}_{2} \mathrm{O}$ 硝子は $580 \mu \mu$ から $620 \mu \mu$ に小凸 起を有するが、曲線の上昇は $640 \mu \mu$ 邊から急激に初まつて居る。又 $\mathrm{K}_{2} \mathrm{O}$ の硝子は $460 \mu \mu$ 以下 に於ては $\mathrm{Na}_{2} \mathrm{O}$ 硝子よりも透過率よく、之等の曲線から $\mathrm{K}_{2} \mathrm{O}$ の硝子は青味を帶ひた紫色で、 $\mathrm{Na}_{2} \mathrm{O}$ の硝子は黃褐色又は橙色を帶びた紫色であることが見られる。

(ii) 透過スペクトル。

透過スペクトルを見る䉆めタングステン・アークランプを使用し試片を硝子分光器の前に置き 第 - - 圖

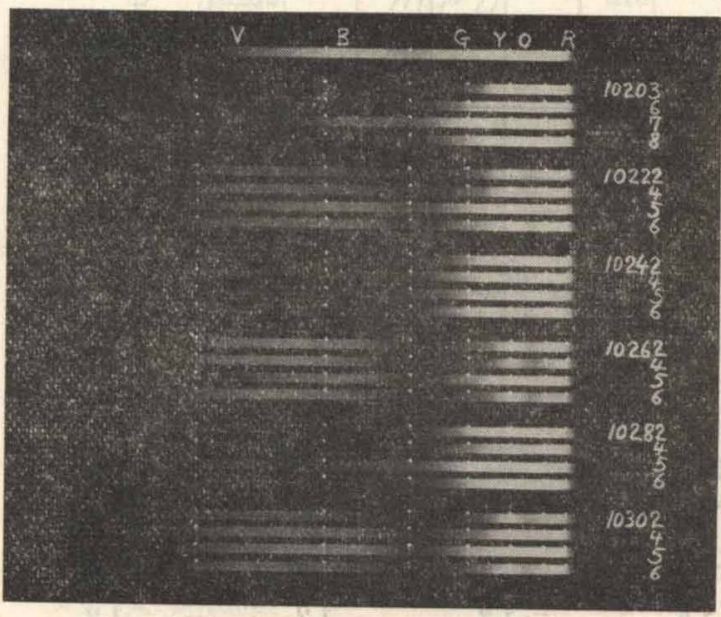
第 - 二 圖

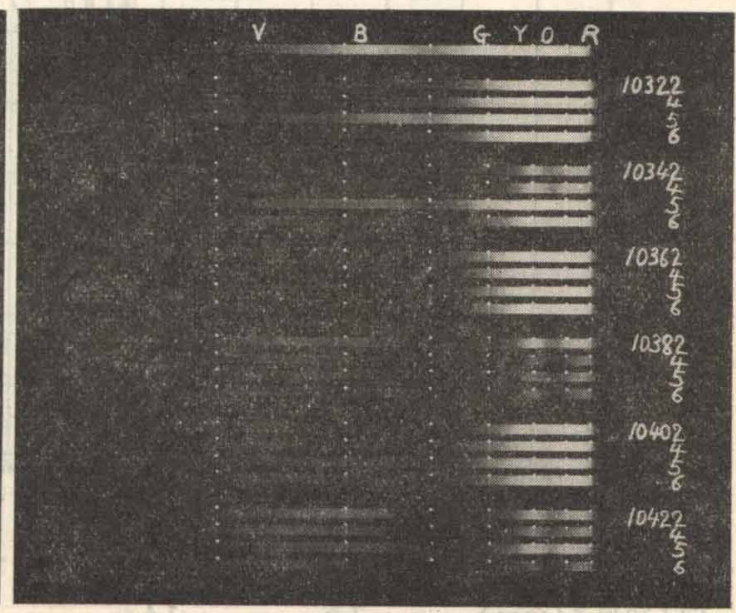

て寫真をとつた。

以上の第一一圖及び第一二圖から見ても曹達硝子は黃から橙の方をよく、加里硝子は靑の方を 
比較的よく透過して居ることを見る。

（c）酸化ニツヶルを加へた硝子の紫外線透過曲線と透過スペクトル。

(i) 透過曲線

ニツヶルの酸化物を加へた硝子の紫外線の透過曲線をャクター・ホトメターにて測定したもの は第一三圖に示した如きものである。

此の第一三圖に示したもの」試料と其の試料の厚さを擧ぐれば次の如をものである。

$$
\text { 第 一三圖 }
$$

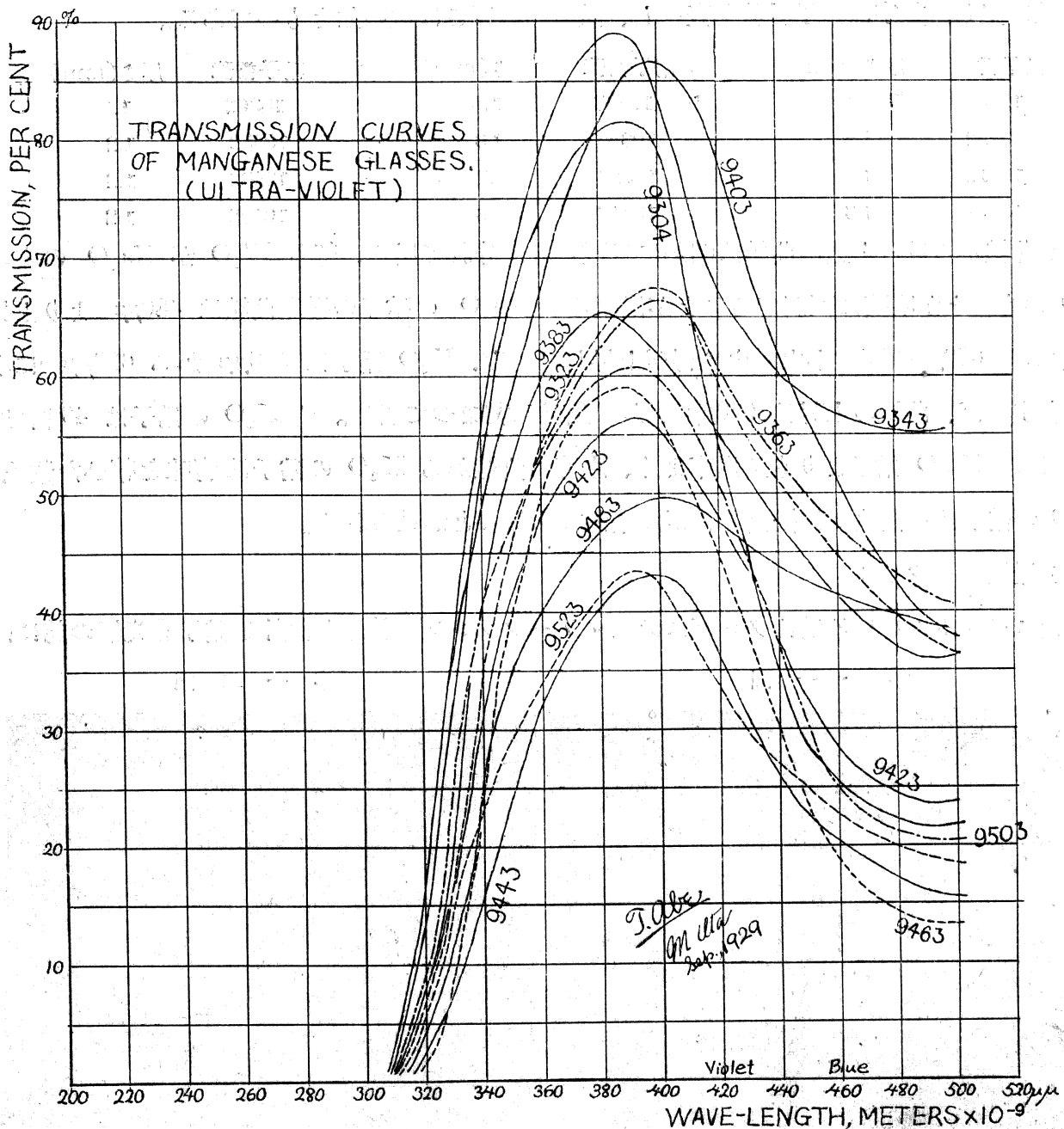

$\begin{array}{lcccccr}\text { 确子番號 } & 10202 & 10242 & 10282 & 10322 & 10362 & 10402 \\ \text { 确子の厚さ }(\mathrm{mm}) & 1.5 & 1.4 & 1.5 & 1.3 & 1.2 & 1.2 \\ \text { 硝子番號 } & 10222 & 10262 & 10302 & 10342 & 10382 & 10422 \\ \text { 硝子の厚さ }(\mathrm{mm}) & 1.4 & 1.3 & 1.3 & 1.3 & 1.2 & 1.2\end{array}$


此の圖より見るに紫外線の透曲率はアルカリが $\mathrm{Na}_{2} \mathrm{O}$ なるか $\mathrm{K}_{2} \mathrm{O}$ なるかによつて變化なし。

(ii) 紫外線の透過スペクトル。

紫外線の透過スペクトルは、水晶空を有するタングステン・アークランプを光源として各種硝 子の透過スペクトルを求めた。

第一四圖及び第一五圖は之れ等のスペクトルの寫㯖である。

第 一 四 圖

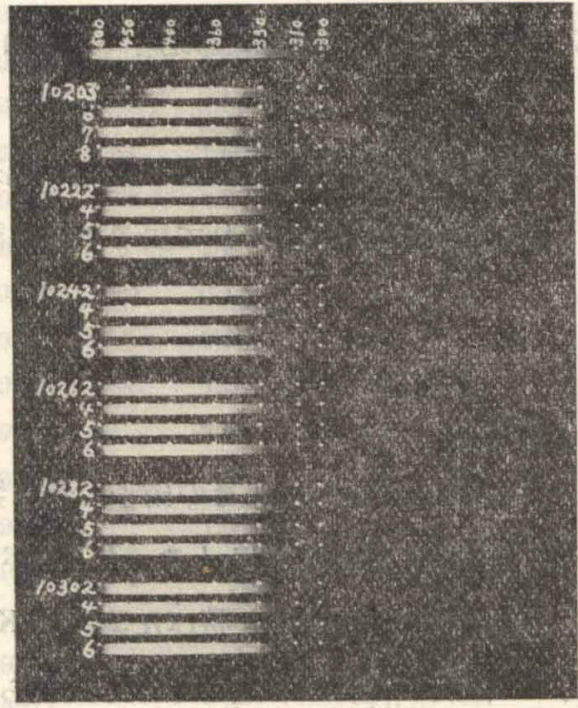

第 一 五 圖

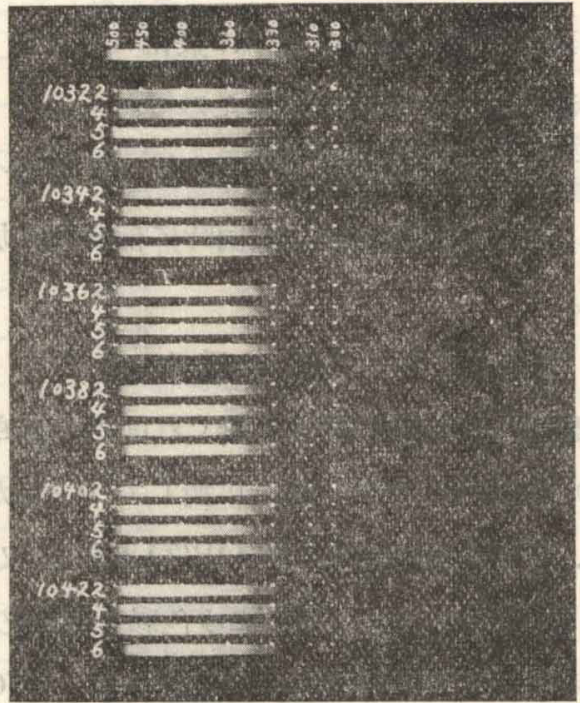

上記の寫真より求めた硝子の厚さと透過する最小波長を示せば次く如くなる。

\section{第 八 表}

矿子番號

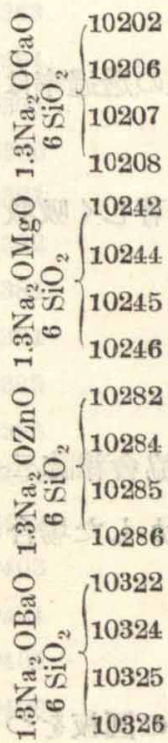

矿子の厚さ透過す万最 (mm) 小波長 $(\mu \mu)$

1.5

1.5

1.6

1.6

1.4

1.4

1.5

1.5

1.5

1.5

1.6

1.5

- 1.3

1.4

1.4

1.4
310

310

310

310

310

310

315

311

310

310

310

310

310

310

310

310
磁子番號

ర్ల $\int_{0}^{10222}$

象 10225

os 10226

ริ 10262

$0^{\circ}\left\{\begin{array}{l}10261 \\ 10265\end{array}\right.$

\begin{tabular}{l|l} 
& 10265 \\
00 & 10266
\end{tabular}

$\begin{array}{ll}-1 & 10266 \\ 0 & 10302\end{array}$

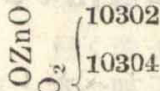

10305

ฮึ 10306

吾 $\int_{10342}^{10344}$

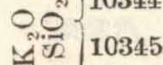

कृ 0 1034
确子の厚さ 透過する最 (mm) 小波長 $(\mu \mu)$

$\begin{array}{ll}1.4 & 310 \\ 1.4 & 310 \\ 1.5 & 310 \\ 1.2 & 310 \\ 1.3 & 310 \\ 1.3 & 310 \\ 1.3 & 328 \\ 1.3 & 310 \\ 1.3 & 310 \\ 1.4 & 310 \\ 1.3 & 310 \\ 1.4 & 310 \\ 1.3 & 310 \\ 1.3 & 310 \\ 1.3 & 310 \\ 1.5 & 310\end{array}$




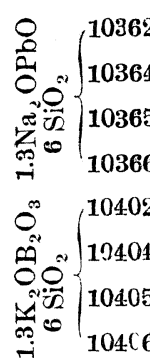

$\begin{array}{ll}1.2 & 318 \\ 1.2 & 318 \\ 1.5 & 327 \\ 1.4 & 320 \\ 1.2 & 309 \\ 1.2 & 309 \\ 1.4 & 310 \\ 1.2 & 309\end{array}$

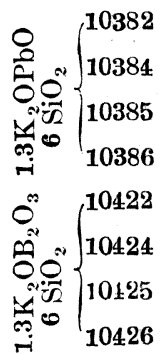

$\begin{array}{ll}1.2 & 319 \\ 1.2 & 319 \\ 1.3 & 348 \\ 1.3 & 319 \\ 1.2 & 308 \\ 1.2 & 308 \\ 1.3 & 310 \\ 1.5 & 310\end{array}$

第八表は各種の成分の硝子に酸化ニツヶル $1.5 \%$ を加へたものと同時に補助劑 1.0 を加へたも のとの透過スペクトルを求めたのである。

此の表から見るも酸化ニツヶルを $0.5 \%$ 加へた雹めに紫外線の吸收率に著しく差違が出來たも のと見ることが出來ない、叉同時に補助劑を加へても其れ等の影響が現はれて居るととも認めら れない。

(d) 酸化ニツケルを加へた硝子の概括。

此の實驗で知り得た概括を舉ぐれば次の如きものとなる。

（i）酸化ニツケルを硝子に對して $0.1 \%$ \% $1.0 \%$ の範圍に加へたときの硝子の色は紫色で あるが、硝子の成分が $1.3 \mathrm{R}_{2}^{\prime} \mathrm{OR}^{\prime \prime} \mathrm{O} 6 \mathrm{SiO}_{2}$ 又は $1.3 \mathrm{R}_{2}^{\prime} \mathrm{OB}_{2} \mathrm{O}_{3} 6 \mathrm{SiO}_{2}$ なるとき、 $\mathrm{R}_{2}^{\prime} \mathrm{O}$ が $\mathrm{Na}_{2} \mathrm{O}$ なるか $\mathrm{K}_{2} \mathrm{O}$ なるかによつて多少色彩を異にして居る、 $\mathrm{Na}_{2} \mathrm{O}$ の時は褐色を帶びた紫色で $\mathrm{K}_{2} \mathrm{O}$ の 時は鮮明なる青色を帶びたる紫色である。 $\mathbf{R}^{\prime \prime} \mathrm{O}$ 几就ては區別する程の相違を來たして居らない。

(ii) 酸化ニツヶルと同時に酸化劑、還元劑又は亞砒酸の如き補助劑を加へても硝子の色彩に 影響なし。

(iii) 酸化ニツケルを加へた硝子の透過曲線を見るに硝子の成分中の $R_{2}^{\prime} \mathrm{O} の$ 相違を著しく現 はして居る。

(iv)酸化ニツケルを $1.0 \%$ 以下加へた硝子の紫外線透過率を見るに紫外線の透過率は酸化= ツヶルを加へた魯めに著しく減少しをと見られず。

（v）從つて酸化ニツヶルは硝子に著しく着色をするものであるが紫外線を著しく吸收するも のでないてとを知る。

\section{8. 二酸化マンガンを加へた硝子の色}

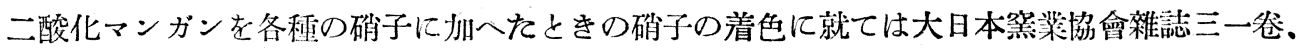
三六六號(大正十二年二月號)に既に發表したものであるが、此處では多量に溶かした場合の着色 狀況に就て更に研究し同時に透過曲線並びに透過スペクトルに就て研究した。

(a) 硝子の成分と着色狀況。

确子の成分と着色狀況並びに補助劑の影響を見る鹞めに徑 $5 \mathrm{~cm}$. 厚さ $5 \mathrm{~mm}$. の圓板をつくつて 
相互に比較し外觀による差異を見た。

第 九 表

\begin{tabular}{|c|c|c|c|c|c|c|}
\hline & 仍子番號 & $\begin{array}{l}\text { 二酸化マシ } \\
\text { ガンの量\% }\end{array}$ & $\begin{array}{l}\text { 酸化劑 } \\
\text { の量\% }\end{array}$ & $\begin{array}{l}\text { 還元劑 } \\
\text { の量\% }\end{array}$ & $\begin{array}{l}\text { 亞䃂酸 } \\
\text { の量\% }\end{array}$ & 砫子 の 色 \\
\hline & 9301 & 0.1 & - & - & - & 殆んど着色なし \\
\hline$S^{n}$ & 9302 & 0.25 & - & - & - & 淡い紫色 \\
\hline & 9303 & 0.75 & - & - & 一 & 濃紫色 \\
\hline & 9304 & 1.00 & - & - & - & 同上 \\
\hline$S^{3}$ & 9305 & 1.50 & - & - & - & 一廨濃厚なろ紫色! \\
\hline$\sum_{\infty}^{\infty}$ & 9306 & 1.0 & 1.0 & - & - & 9304よりも幾分淡きも鮮明な万着色をなす \\
\hline re & 9307 & 1.0 & - & 1.0 & - & 稍や暗色あろ紫色にして着色淡くなる \\
\hline & 9308 & 10 & - & 一 & 1.0 & 極く淡い綠靑色となり紫色消失す \\
\hline & 9321 & 0.1 & - & - & - & 無色 \\
\hline & 9322 & 0.5 & - & - & - & 紫色 \\
\hline 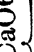 & 9323 & 1.0 & - & - & - & 濃き鮮明なろ紫色 \\
\hline$\sum_{n}^{2}$ & 9324 & 1.0 & 1.0 & - & - & 同上 \\
\hline 告. & 9325 & 1.0 & - & 1.0 & - & 淡き紫色 \\
\hline$-i$ & 9326 & 1.0 & - & - & 1.0 & 同上 \\
\hline & 9341 & 0.1 & - & - & - & 無色 \\
\hline 空 & 9342 & 0.5 & - & - & - & 淡き赤味あろ紫色 \\
\hline 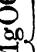 & 9343 & 1.0 & - & - & - & 赫味あ万紫色 \\
\hline 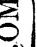 & 9344 & 1.0 & 1.0 & - & - & 濃き赤味あろ紫色 \\
\hline$\overbrace{}^{\infty}$ & 9345 & 1.0 & - & 1.0 & - & 淡き帶綠色 \\
\hline & 9346 & 1.0 & - & - & 1.0 & 僅かに帶褐紅色杂停も \\
\hline & 9361 & 0.1 & - & - & - & 殆んど着色なし \\
\hline 8 & 9362 & 0.5 & - & - & - & 紫色 \\
\hline (2) & 9363 & 1.0 & - & - & - & 稍や濃き紫色 \\
\hline $\bar{O}_{-1}$ & 9364 & 1.0 & 1.0 & - & - & 稍や赤味あろ紫色 \\
\hline$\frac{\ddot{H}}{m}$ & 9365 & 1.0 & - & 1.0 & - & 帶紅紫色 \\
\hline$-i$ & 9366 & 1.0 & - & - & 1.0 & 極く淡寻紶色 \\
\hline 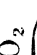 & 9381 & 0.1 & - & - & - & 殆んど笪色なし \\
\hline 至 & 9382 & 0.5 & - & - & - & 赤味ある紫色 \\
\hline ] & 9383 & 1.0 & - & - & - & 濃寻沙味めろ紫色 \\
\hline O. & 9384 & 1.0 & 1.0 & - & 一 & 一㿉䟴くなろ \\
\hline $\mathrm{z}_{-\infty}^{\infty}$ & 9385 & 1.0 & - & 0.1 & - & 微帶綠色 \\
\hline - & 9386 & 1.0 & - & - & 1.0 & 極く淡き帶紅褐色 \\
\hline $0^{\circ}$ & 9401 & $0 \cdot 1$ & - & - & - & 淡紅色 \\
\hline 要 & 9402 & 0.5 & - & - & - & 淡紫色 \\
\hline ర્ష & 9403 & 1.0 & - & - & - & 濃紫色 \\
\hline Oे & 9404 & 1.0 & 1.0 & - & - & 一ー㞒濃くなろ \\
\hline$\frac{1}{\infty}$ & 9405 & 1.0 & - & 1.0 & - & 淡紫色 \\
\hline$-i$ & 9406 & 1.0 & $\therefore-$ & - & 1.0 & 一尿淡くなろ \\
\hline
\end{tabular}




\begin{tabular}{|c|c|c|c|c|c|c|}
\hline \multirow{2}{*}{\multicolumn{2}{|c|}{ 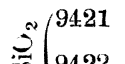 }} & 0.1 & - & - & - & 微かに絩色を带ぶ \\
\hline & & 0.5 & - & - & - & 赫味あ万淡色にして䅌や暗色おり \\
\hline \multirow{2}{*}{$\begin{array}{l}0 \\
0 \\
0 \\
0\end{array}$} & 9423 & 1.0 & -- & - & - & 紫色 \\
\hline & 9424 & 1.0 & 1.0 & - & - & 同上 \\
\hline \multirow{2}{*}{ 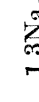 } & 9425 & 1.0 & - & 1.0 & - & 淡黄色 \\
\hline & 9426 & 1.0 & - & - & 1.0 & 極く淡寻帶褐紅色 \\
\hline \multirow{6}{*}{$\begin{array}{l}0 \\
0 \\
0 \\
0 \\
0 \\
0 \\
0 \\
0 \\
0 \\
0\end{array}$} & 9441 & 0.1. & - & - & - & 淡畟色 \\
\hline & \multirow[t]{2}{*}{9442} & 0.5 & - & - & - & 紫色 \\
\hline & & 1.0 & - & - & - & 濃き鮮明な万紫色 \\
\hline & 9444 & 1.0 & 1.0 & - & - & 同上 \\
\hline & \multirow{2}{*}{$\mid \begin{array}{l}944 \\
944\end{array}$} & 1.0 & - & 1.0 & - & 僅かに綠色虎呈す \\
\hline & & 1.0 & - & - & 1.0 & 濃紫色 \\
\hline \multirow{6}{*}{ 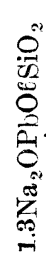 } & \multirow{3}{*}{$\begin{array}{l}946 \\
946 \\
946\end{array}$} & 0.1 & - & - & - & 極く淡い紅色 \\
\hline & & 0.5 & - & $\cdots$ & - & 赫味ある紫色 \\
\hline & & 1.0 & 一 & - & - & 濃紫色 \\
\hline & \multirow{2}{*}{$\begin{array}{l}946 \\
946\end{array}$} & 1.0 & 1.0 & - & - & 同上 \\
\hline & & 1.0 & - & 1.0 & 一 & 澧き赤味あ万紫色 \\
\hline & (9466 & 1.0 & - & - & 1.0 & 赤味あろ紫色 \\
\hline \multirow{6}{*}{ 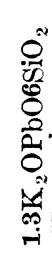 } & \multirow{2}{*}{$\left(\begin{array}{l}9481 \\
9482\end{array}\right.$} & 0.1 & - & - & - & 美しき淡紫色 \\
\hline & & 0.5 & - & - & - & 鮮明なる紫色 \\
\hline & 9483 & 1.0 & 一 & - & - & 濃紫色 \\
\hline & 9484 & 1.0 & 1.0 & - & - & 同上 \\
\hline & 9435 & 1.0 & - & 1.0 & - & 濃紫色少しく赤味おり \\
\hline & 9456 & 1.0 & - & - & 1.0 & 極く淡专帶紅色 \\
\hline \multirow{6}{*}{ 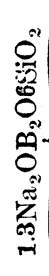 } & 9501 & 0.1 & - & - & - & 極く淡い帶紅色 \\
\hline & 9502 & 0.5 & - & - & - & 淡い帶紅色 \\
\hline & 9503 & 1.0 & - & - & - & 濃紫色 \\
\hline & 9504 & 1.0 & 1.0 & - & - & 同上 \\
\hline & 9505 & 1.0 & 一 & 1.0 & - & 稍や淡くなる \\
\hline & 9506 & 1.0 & - & - & 1.0 & 暗色な帶びたる淡帶紅紫色 \\
\hline \multirow{6}{*}{ 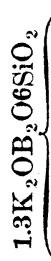 } & 9521 & 0.1 & - & - & - & 極く淡き紫色 \\
\hline & 9522 & 0.5 & - & - & - & 鮮明なる紫色 \\
\hline & 9523 & 1.0 & - & - & - & 濃き鮮明な万紫色 \\
\hline & 9524 & 1.0 & 1.0 & - & - & 同上 \\
\hline & 9525 & 1.0 & - & 1.0 & - & 同上 \\
\hline & 9526 & 1.0 & - & - & 1.0 & 淡紫色となり多少赤味な帶ぶ \\
\hline
\end{tabular}

第儿表の結果から見ると、二酸化マンガンを $0.1 \%$ 加へたものは鉛硝子と硯珪酸硝子以外には 紫色を呈したものはない。0.5\%に至り初めて何れの硝子も濃淡はあるが紫色を現はして居る。 硝子成分 $1.3 \mathrm{R}_{2}^{\prime} \mathrm{O} \mathrm{R} \mathrm{R}^{\prime \prime} \mathrm{O} 6 \mathrm{SiO}_{2}$ の $\mathrm{R}_{2}^{\prime} \mathrm{O}$ が $\mathrm{Na}_{2} \mathrm{O}$ の時は概して赤味を帶びた紫色を呈し、 $\mathrm{K}_{2} \mathrm{O}$ の時は㙰明な美しき紫色を呈する傾向がある。

$\mathrm{R}^{\prime \prime} \mathrm{O}$ に就ては區別はないが鉛硝子と矹珪酸硝子とが他よりも濃い着色をなして居る㥞である。 二酸化マンガンを硝子調合中に加へる際に同時に酸化劑を加へると紫色の着色が稍や浱くなる 
かメは變化がないが、還元劑を加へると硝子の着色に著しき變化を與へて或るものは殆んど着色

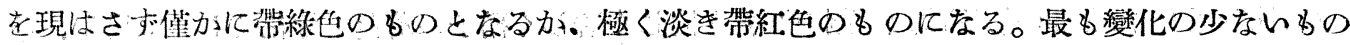
でも紫色の濃さに著しい變化を與へ、1:0\%の二酸化マンガンを加へたものが $0.25 \%$ 程度を加一 たと导の着色程度に淡くするものも市る。或は紫色の減少は餘り著しくをくも同時に赤味を帶び たものに變色したものもある。還元劑を加へたもので最も着色に影響の少ないものは鉛硝子と眮

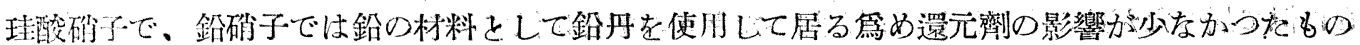
と見るととが出來る。

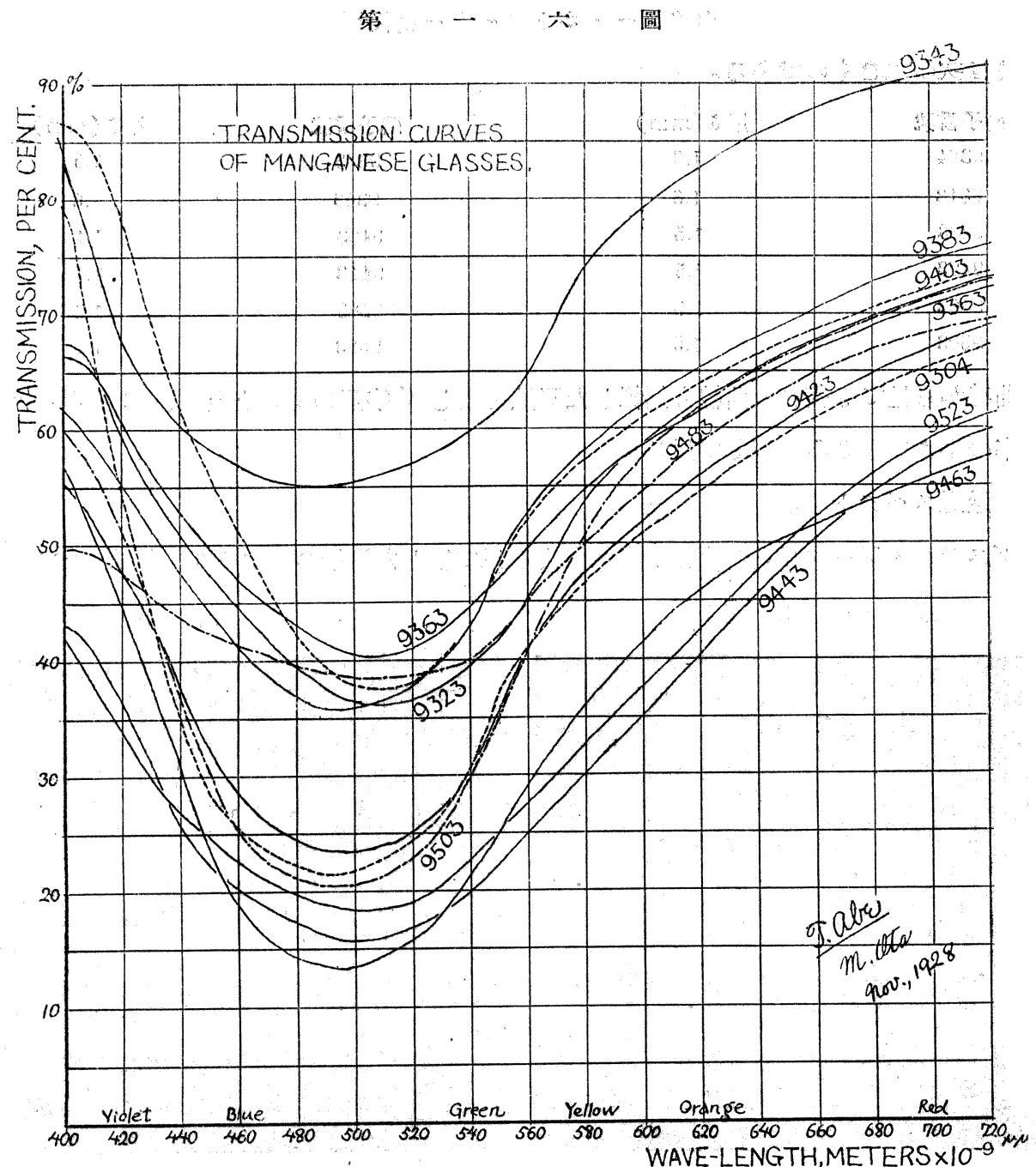

それ等よりして二酸化マンガンを加へたときの紫色は $\mathrm{MnO}_{-2}$ 又は $\mathrm{Mn}_{2} \mathrm{O}_{3}$ の着色で、還元制 を加へたときはマンガンの酸化物の還元が起つて $\mathrm{MnO}$ となる䉆め紫色を現はさないものと見 
るととが出來る。

亞砒酸を加へたときの影響は還元劑の影響と同じく著しく硝子の着色を變化せしめて居る、殆 ぞ何れの硝子も亜砣酸を加へた䳕めに着色が破壞されて著しく淡色のものとなり大體に於て帶紅 色を呈するに至つて居る。

酸化鐵又は酸化ニツケルを加へたときの亞砣酸の影響は寧ろ其の着色狀況は酸化唰をを加へたと きに似て居つたが此の瑒合は還元劑を加へたときの變化に似て居る。

(b) 二酸化マンガンを加へた硝子の透過スペクトル。

(i) 透過曲線はヒルガーのセクター・ホトメーターを使用して求めた試料に使用した硝子と 其の厚さは次の如きものである。

\begin{tabular}{cccc|} 
确子番號 & 厚さ $(\mathrm{mm})$ & 硝子番號 & 厚さ $(\mathrm{mm})$ \\
$93 J 4$ & 1.6 & 9323 & 1.5 \\
9343 & 1.6 & 9363 & 1.6 \\
9383 & 1.5 & 9403 & 1.4 \\
9423 & 1.5 & 9443 & 1.5 \\
9463 & 1.5 & 9483 & 1.5 \\
9503 & 1.5 & 9523 & 1.7
\end{tabular}

此の曲線から見ても何れの曲線も類似した形狀をなし V 字形のものとなり、其つ $500 \mu \mu$ 附近 に透過率の小さなとてろを有して居る。

(ii) 透過スペクトル。

タングステン・アークランプと硝子分光器とを以て寫した透過スペクトル竄真次の如し。

\section{第 一 七 圖}

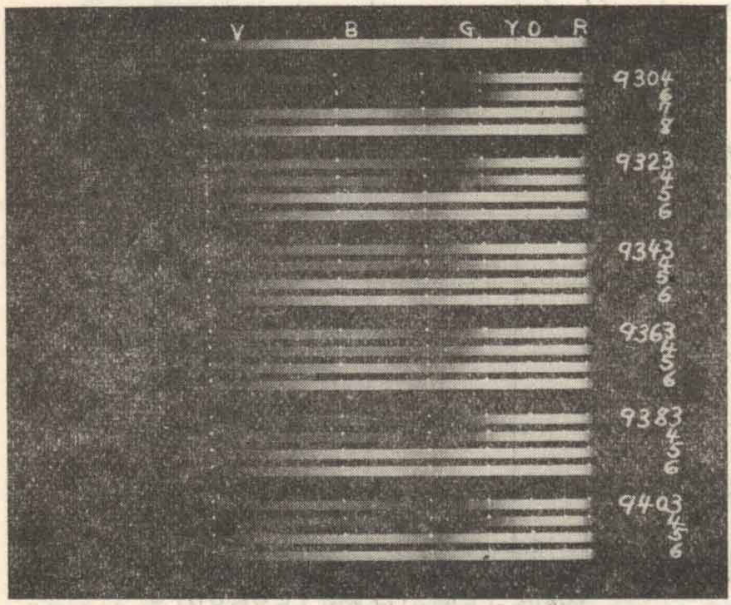

第 一 $八$ 圖

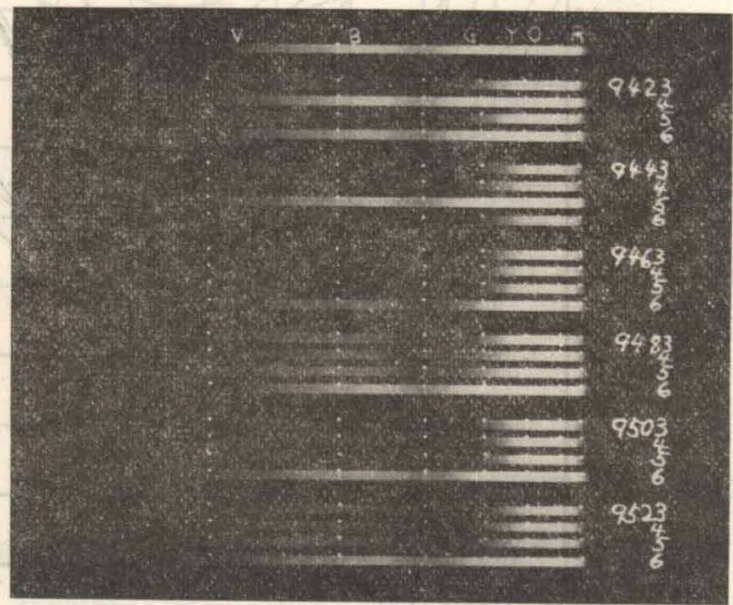

第一七圖及び第一八圖の試料及び其の厚さに就ては紫外線透過スペクトルの項に記載す。

（e）二酸化マンガンを加へた硝子の紫外線透過曲線並びと透過スペクトル。

(i) 紫外線透過曲線。 
二酸化マンガンを办へた硝子の紫外線透過曲線を求める雼めに、セクター・ホトメーターと石英 分光器を使用した。

第一古 圖

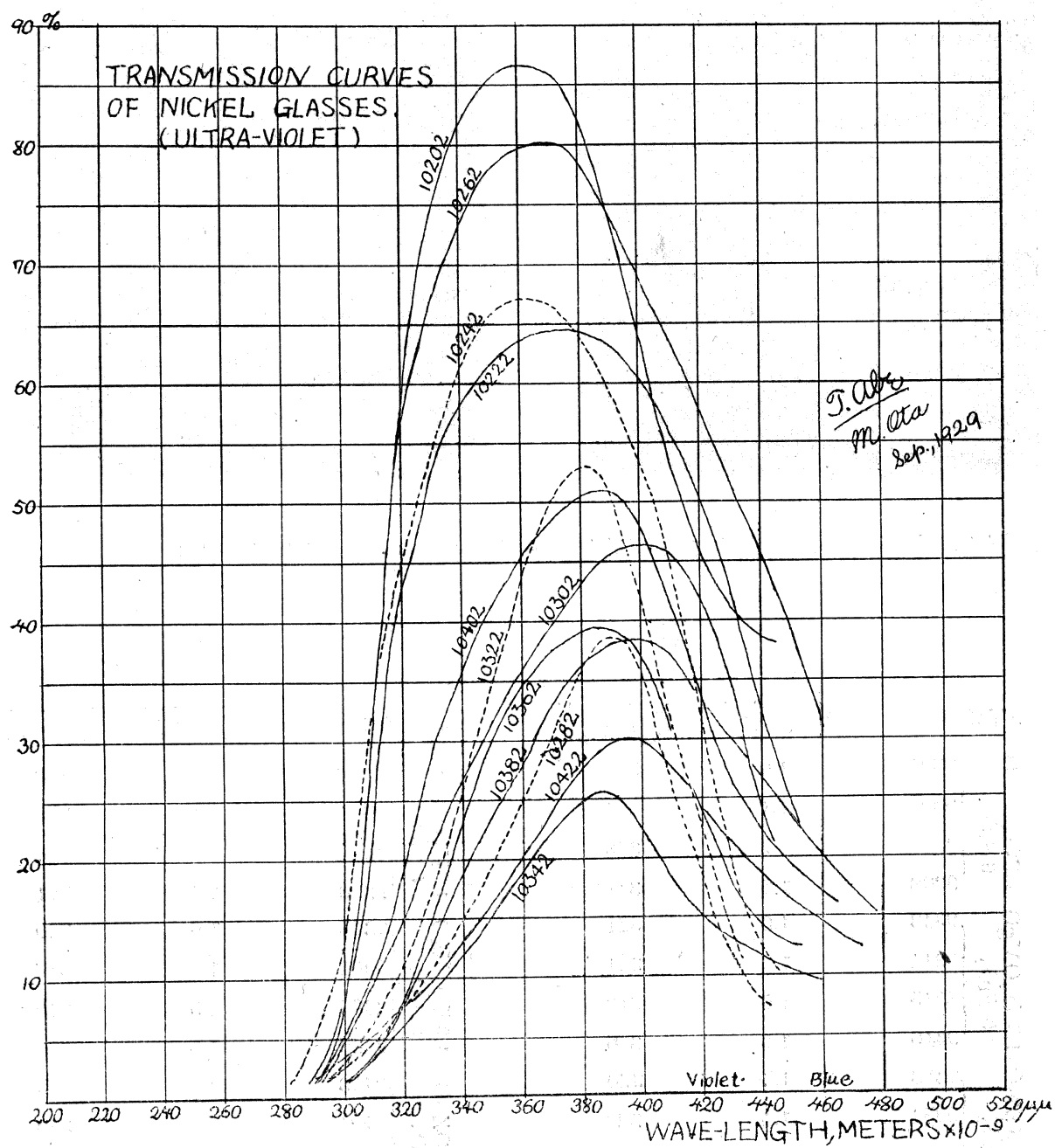

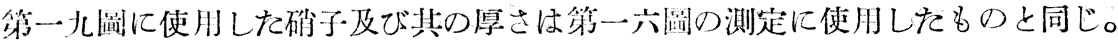

此れによれば近紫外線即ち $390 \mu \mu$ 附近から總ての确子は透過率を減少して $310 \mu \mu$ 邊までを透 過して居るが、大體の傾向は二酸化マンガンを加へた真めに著しく紫外線を吸收するものとなつ たとは見られない。

(ii) 紫外線の透過スペクトル。

石英空を有する固定極タングステン・アークランプと石英分光器で透過スペクトルを弿した。 此の時の露出 20 秒とした。 
第

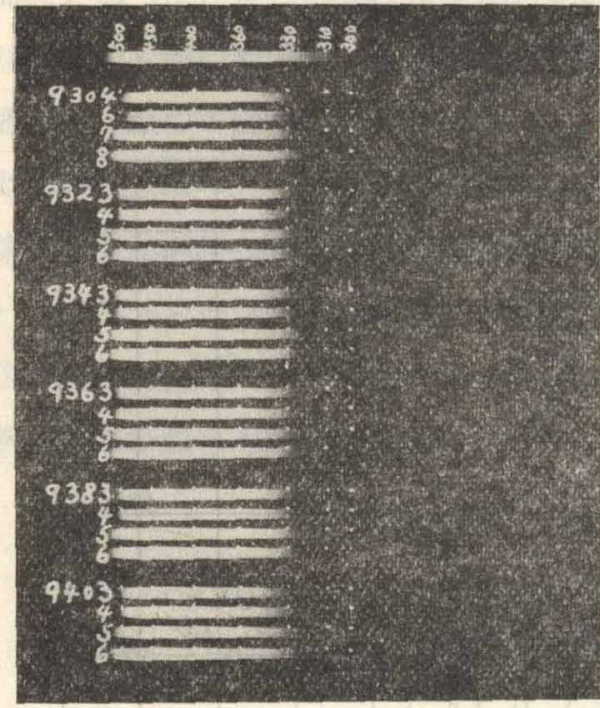

第 二 $\rightarrow$ 高

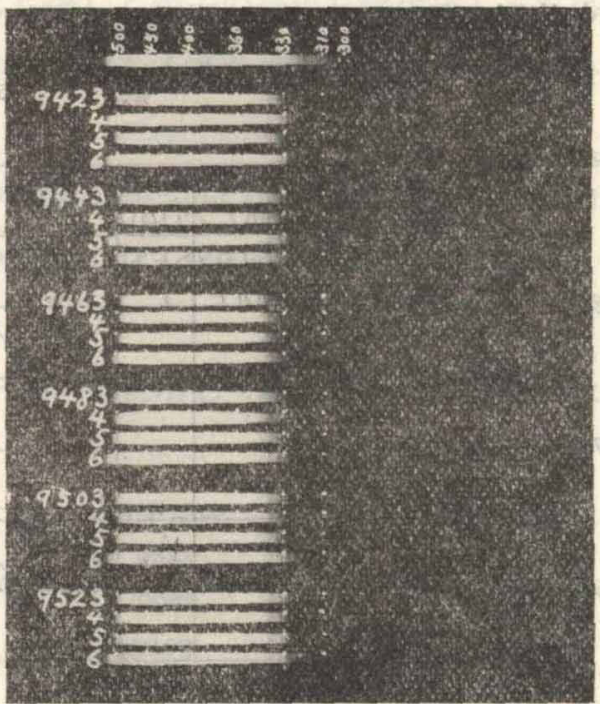

此の寫県より各の硝子の透過する最短波長老舉ぐれば第一○表の如くである。

\section{第 $\rightarrow 0$ 表}

确子番號

$\overbrace{0.0}^{\circ}\left\{\begin{array}{l}9304 \\ 9306\end{array}\right.$

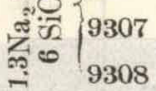

章般 $\int_{9344}^{9343}$

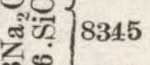

๑

ํำ 9383

赵 9385

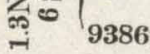

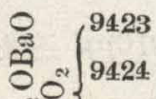

ธะกำ 9425

๑

官 $\int_{9464}^{9463}$

丞|
确子の厚さ透過す万最 (mm) 短波長 $(\mu \mu)$

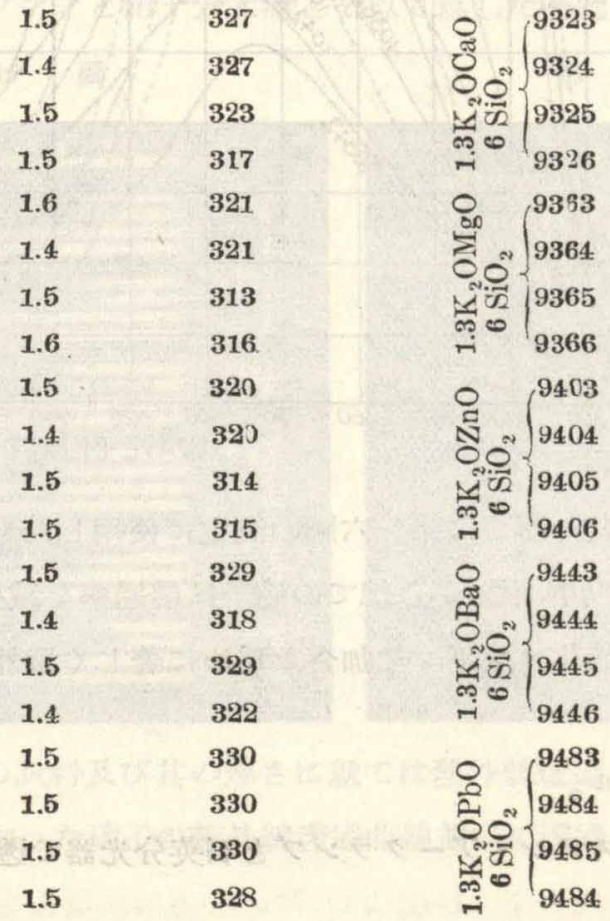

确子の厚さ䢤過すろ最 (mm) 短波長 $(\mu \mu)$

$1.5 \quad 323$

$1.4 \quad 325$

$1.4 \quad 320$

$1.4 \quad 321$

$1.6 \quad 320$

$1.5 \quad 320$

$1.5 \quad 319$

$1.5 \quad 320$

$1.4 \quad 318$

$1.6 \quad 319$

$1.5 \quad 319$

$1.4 \quad 313$

$1.5 \quad 329$

$1.5 \quad 329$

$1.4 \quad 322$

$1.3 \quad 327$

$1.5 \quad 328$

$1.4 \quad 329$

$1.5 \quad 328$

1.2 326 


$\begin{array}{ll}1.5 & 328 \\ 1.5 & 327 \\ 1.5 & 328 \\ 1.5 & 322\end{array}$

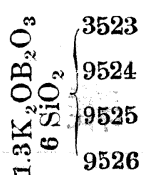

1.7

1.5

1.5

1.5
322

327

325

322

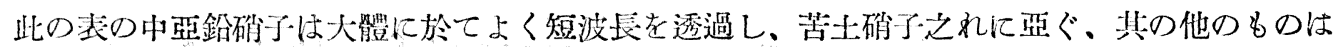
鉛确子を除いては大體類似した倾向を有して居る。

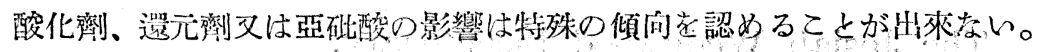

二酸化マンガンを $1.0 \%$ 位加へた确子では $1.5 \mathrm{~mm}$ 附近の厚さのものは透過する最短波長は

$315 \mu \mu$ から $330 \mu \mu$ 附近ののとしで差支えなし。

(d) 二酸化マンガンを加へを硝子の概括。

以上の研究によつて得をる概括は次の如きものである。

(i) 二酸化マンガンを各種の成分の硙子几加へたときの硝子の色は紫色であるが、确子の成 分 $1.3 \mathrm{R}_{2}^{\prime} \mathrm{OR}^{\prime \prime} \mathrm{O} 6 \mathrm{SiO}_{2}$ 又は $1.3 \mathrm{R}_{2}^{\prime} \mathrm{OB}_{2} \mathrm{O}_{3} 6 \mathrm{SiO}_{2}$ に於て $\mathrm{R}_{2}^{\prime} \mathrm{O}$ が $\mathrm{Na}_{2} \mathrm{O} の$ 時は赤味を帶び $\mathrm{K}_{2} \mathrm{O}$ の時は鮮明な紫色を呈す。

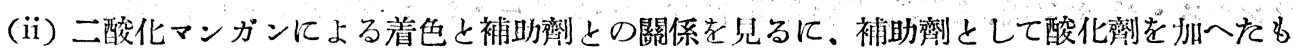

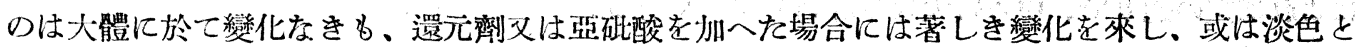
なる、甚だしきものは無色となる。之れ等よりして二酸化マンガンを加へたときの硝子の紫色は マンガンの高度の酸化物の着色で、酸化の度の低きものは着色せざるるのであるととを推測する ことが出來る。

（iii）透過曲線より見るときは、大體て於て青と綠との透過率少なく、スペクトルを見るも 還元劑又は亞砒酸を加へたものに選擇的の吸收ををてとを見る。

(iv）紫外線の吸收率は少量の二酸化マンガンを加へることによつて影響なし。 